\title{
Çağdaş Sanatta Yazı: Seramik Malzemenin Plastik Dili Üzerinden Bir Değerlendirme
}

\section{Inscriptions in Contemporary Art: An Evaluation on The Plastic Language of Ceramic Works}

\section{Safiye Bașar}

Doç. Dr., Kocaeli Üniversitesi Güzel Sanatlar Fakültesi Seramik Bölümü

email: safiyebasar@yahoo.com (DORCID ID: https://orcid.org/0000-0003-1958-714X

Atıf (APA 6)/To cite this article

Başar, S. (2019). Çağdaş sanatta yazı: seramik malzemenin plastic dili üzerinden bir değerlendirme. Atatürk Üniversitesi Güzel Sanatlar Enstitüsü Dergisi, 43, 222-233. doi: https://doi.org/10.32547/ataunigsed.606167

Makale Gönderim Tarihi/Received: 19/08/2019

Makale Kabul Tarihi/Accepted: 20/09/2019

Makale Yayın Tarihi/Published: 26/10/2019

Review Article/Derleme Makalesi

$\ddot{O} z$

MÖ yaklaşık 3000'lerde Sümerler tarafindan geliştirilen yazı, bir bellek yardımcısı ve iletişim aracıdır. Tarihsel olayların belgelenmesinde, edebi metinlerin, mitlerin, dini ilahilerin bu güne ve geleceğe aktarılmasında önem taşır. 20. Yüzyılın başlarında yazı edebiyatın alanından sızarak, Kübist ve Dadaist sanatçıların çalışmalarında plastik yapıyı zenginleştiren görsel bir imgeye dönüsmüștür. Yüzyılın ikinci yarısında ise izleyicinin estetik deneyimden ziyade, zihinsel bir sorgulama sürecine yönlendirildiği kavramsal çalışmalarda başat bir öge olarak öne çıkmaktadır. Joseph Kosuth, Lawrence Weiner'ın çalışmalarında sanatsal temsilin yerini alan metin, geçtiğimiz yüzyılın sanatında bir kırılma olușturmustur. Bu kırılmanın etkisi resimden heykele, performanstan seramik sanatına değin yayılır. Üretimlerinde seramik malzemenin dilini ve tarihsel bağlamını kullanan Patrick King, Jeanne Opgenhaffen, Marianne Requena gibi sanatçıların çalışmalarında yazı hem plastik bir unsur, hem de dilsel bir ifade aracı olarak karşımıza çıkmaktadır.

Anahtar Kelimeler: Çağdaş Sanat, Yazı ve Sanat, Metin, Çağdaş Seramik

\begin{abstract}
Inscription developed by the Sumerians around $3000 \mathrm{BC}$ is a helper for memory, and a thinking and communication tool. It is important for transferring historical events, myths and religious hymns to the future. At the beginning of the 20th century, inscriptions became a visual image that enriched the plastic structure in the works of Cubist and Dadaist artists. In the second half of the 20th century in the conceptual studies where the audience is directed to a process of mental inquiry rather than aesthetic experience, it stands out as a dominant element. In the conceptual works of Joseph Kosuth, Lawrence Weiner, and of Cengiz Cekil, 'text' replaces of artistic representation. Artists such as Patric King, Jeanne Opgenhaffen and Marianne Requena use the plastic language and historical context of ceramic material in their works, and in these kind of works, text and inscription appear as a plastic element and a visual image.
\end{abstract}

Keywords: Contemporary Art, Inscription and Art, Text, Contemporary Ceramic

\section{Giriş}

Sanatın ontolojik olarak değişime uğradığı 20. yüzyılda 'yazı' edebiyatın alanından plastik sanatlar alanına doğru sıçrayarak, görsel ifadenin bir parçasına dönüşmüştür. Stephane Mallerme ve Guillaume Apollinaire'in şiirlerinde izlenen görsel arayışlar, kaligramlar, kendilerinden sonra gelen pek çok sanatçı için esin kaynağı olmuştur. Şekilli dizeler olarak tanımlanabilecek kaligramların, plastik sanatlar içinde yazının görsel bir eleman olarak kullanımının ve yaygınlaşmasının önünü açtığı söylenebilir.

Yazı/metin Kübist ve Dadaist kolajlarda görsel bir imge olarak karşımıza çıkarken, Sürrealist çalışmalarda dil ve imge arasındaki ilişkiyi yıkmıştır. Yirminci yüzyılın ikinci yarısında ise kavramsal çalışmalarda, yazı ve metnin sanatsal temsilin yerini aldığı görülür. Günümüz sanatında, yazı hem görsel bir imge, hemde dilsel bir ifada aracı olarak karşımıza çıkmaya devam etmektedir. Bu araştırma çağdaş sanatta yazının 'görsel imge' olarak kullanımından daha ziyade, 'dilsel ifade aracı' olarak varlığına odaklanır. Yazı ve metnin içeriği sanatsal anlamın inşasında belirleyici midir? Bu sorunun cevapları seramik malzemenin plastik dili ve tarihsel bağlamı üzerinden üretilen yapıtlarda bulunmaya çalışılmıştır.

Araştırmanın ilk bölümünde yazının gelişimi ve tarihsel perspektifte seramik yüzeylerde kullanımı üzerinde durulmuştur. İkinci bölümde ise sanatın yazıyla buluştuğu örnekler saptanarak, sonrasında seramik malzemenin dili üzerinden gelişen yapıtlar analiz edilmiştir.

\section{Yöntem}

Konunun derinlemesine irdelenmesinde betimleyici yöntem kullanılmıştır. Yazının ortaya çıkışı, tarihsel gelişim süreci, çağdaş sanatla keşişme noktalarında ortaya çıkan örneklerin elde edilmesinde nitel veri toplama tekniğinden yararlanılmıştır. Literatür taraması, konuya ilişkin sanat yapıtı incelemeleri, sanatçılarla yapılan 
görüşmeler, araştırmanın temel dayanak noktasını oluşturmaktadır. Literatürde yeterli veriye ulaşılamayan sanatçılar ile görüşmeler yapılarak çalışmaları hakkında bilgi edinilmiştir.

\section{Yazının gelişimi ve tarihsel perspektifte seramik yüzeylerde kullanımı}

İnsanlık tarihinde bir dönüm noktası olarak kabul edilen yazının serüveni oldukça uzun ve bilinmezlik içermektedir. İnsanoğlunun kendini ifade etme ihtiyacıyla başlayan bu serüven resimsel anlatımdan simgesel ifadeye, yazıya doğru evrilmiştir. Yazıya geçiş yaklaşık M.Ö 3000'leri bulur. Bu geçiş, Chauvet Mağarası'ndaki resimlerden 27 bin yıl; Göbekli Tepede ele geçen dikili taş kabartmalarından yaklaşık 7000 bin yıl sonrasına denk düsşer (Clare, 2019). Temelde bir iz bırakma eylemi olarak yazı, başlangıçta kil tabletler üzerine belirli işaretlerin çizilmesiyle oluşturuldu. Sümerlerin ziraat ürünlerinin, depo ve tapınaklardaki malların kayda geçirilmesinde kullandıkları resimli yazı, pigtogramlar, çivi yazısının erken evresi olarak kabul edilebilir. Sümerler, bu erken evrede belirli nesne ve varlıkları ifade etmede pigtogramları kullanmış, daha sonra doğrudan nesneyi resimlemek yerine ses açısından onunla benzerlik taşıyan bir başka nesneden yararlanma düşüncesini ortaya atmışlardır (Georges, 2010, s. 17).

Yazının Sümerler tarafindan geliştirilmesinin ardından Akadlar, Babiller, Asurlar, Hititler ve Mısırlılar da kil tabletler üzerinde çivi yazısını kullanmışlardır (Okur, 2007, s.9). Başlangıçta basit bir muhasebe işlemi için ortaya konulan yazı, "Mezopotamyalılar için önce bir bellek yardımcısı, sonrada konuşma dilinin izlerini koruma yöntemi, hatta iletişim kurmanın, düşünmenin, ifade etmenin farklı bir aracı olmuştur" (Georges, 2010, s. 18). Şüphesiz, edebi metinlerin, mitlerin, dini ilahilerin, anıların, tarihsel olayların belgelenmesinde, dolayısıyla bu güne ve geleceğe taşınmasında en önemli araçtır.

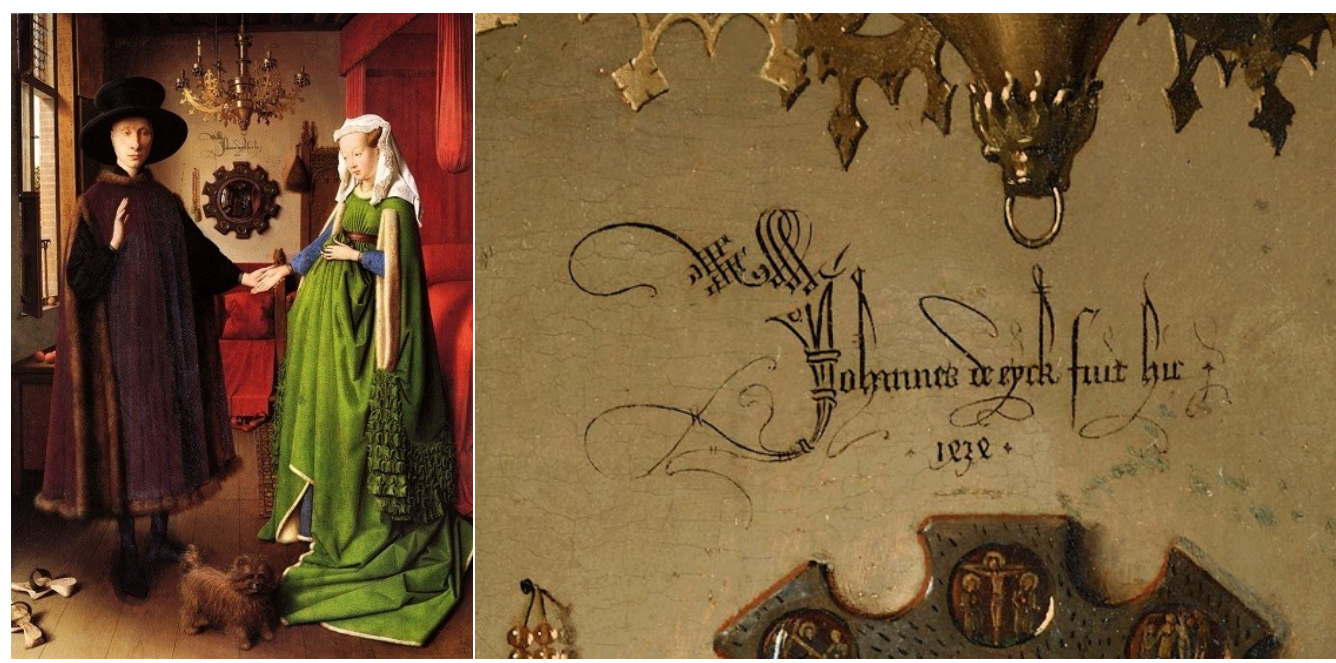

Görsel 1. Jan Van Eyck, Arnolfini’nin Evlenmesi, 1434

Yazının belge niteliğinin yanında salt görsel bir unsur olarak sanatsal çalışmaların içine eklemlenmesi yaklaşık 15. Yüzyılın ilk çeğreğinde gerçekleşir. Sanat tarihinde Jan Van Eyck'ın 'Arnolfini'nin Evlenmesi' adlı çalı̧̧ması yazının plastik bir unsur olarak kullanıldığı ilk örnek olarak kabul edilir (Stokstad, 1995, s. 624). Ancak bu örnekten çok daha önceleri, batı resminin kökeni olarak kabul edilen Yunan 'vazo resmi' geleneğinde, İslam seramiklerinde yazının hem bir belge, hem de görsel bir eleman olarak kullanıldığı çok sayıda örneğe rastlamak mümkündür. Yunan seramiklerinde çoğunlukla, çömlekçi ve ressamın ismi, iyi niyet dilekleri, mitolojik kişi ve karakterlerin sözlü ifadeleri zaman zaman müzik ve notalara ilişkin içeriğe rastlanır (Chiarini, 2018, s.2). İslam Sanatında mimaride kullanılan seramik örneklerde çoğunlukla Kuran'dan kutsal metinler yer alır. Günlük kullanıma yönelik işlevsel seramiklerde iyi niyet dilekleri, özdeyişler ve nadirende olsa çömlekçi ustasını ifade eden yazılarla karşılaşılır (Graber, 1988, s. 142; Bulut, 1994, s.6).

Tarihsel ve mitolojik olayları konu alan Yunan vazo resmi geleneğininde, resimsel betimlemelerle birlikte yazının görsel bir unsur olarak kullanıldığ görülür. Ele geçirilen en eski buluntular Homorik şiir örnekleri içerir. MÖ 8. yy'la tarihlenen bu örneklerin ilkinde 'Her kimki dansçılar içinde en çok dans ediyorsa ödülü o alacaktır' ifadesi; ikinci örnekte ise 'Ben Nestor'un içki kupasıyım. Her kimki bu kupadan içerse, arzu ve güzellik tanrısı Afrodite ulaşır' ifadeleri yer alır (Voutiras, 2007, s. 273). Kırık seramik parçaların yüzeylerinde görülen bu en eski buluntuların dışında, Yunan vazo resmi geleneğinde yazının kullanıldığı en etkili örnekler arasında 'Oyun Oynayan Ajax ve Aşil' adlı Attika vazosu ile Francois vazosu sayılabilir.

MÖ 540-560 yıllarına tarihlenen 'Oyun Oynayan Ajax ve Aşil' adlı Attika vazosu, çömlekçi ve ressam Exekias'ın imzasını taşır. Siyah figür geleneğindeki bu vazo üzerinde Troya savaşının mitik iki kahramanı, Ajax ve Aşil, taş oyunu oynarken betimlenmiştir. Her iki kahraman üzerlerindeki isimleriyle tanımlanır. 
Betimlemenin en dikkat çeken özelliği ise figürlerin ağız hizasından aşağıya doğru yönelen yazı dizisidir. Așilin ağzından dökülen teserra (dört), Ajax’ın ağzından dökülen tria (üç) sözcükleri izleyicide adeta taş oyununun canlı tanığ 1 olduğu hissi uyandırmaktadır (Kleiner, 2010, s. 100). Yunan mitolojisinde bu iki karakterin oyun

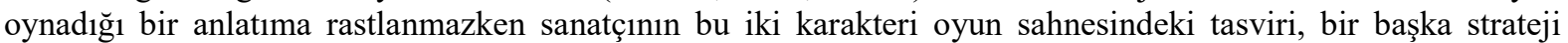
oyunu Truva savaşına gönderme olarak değerlendirilebilir.
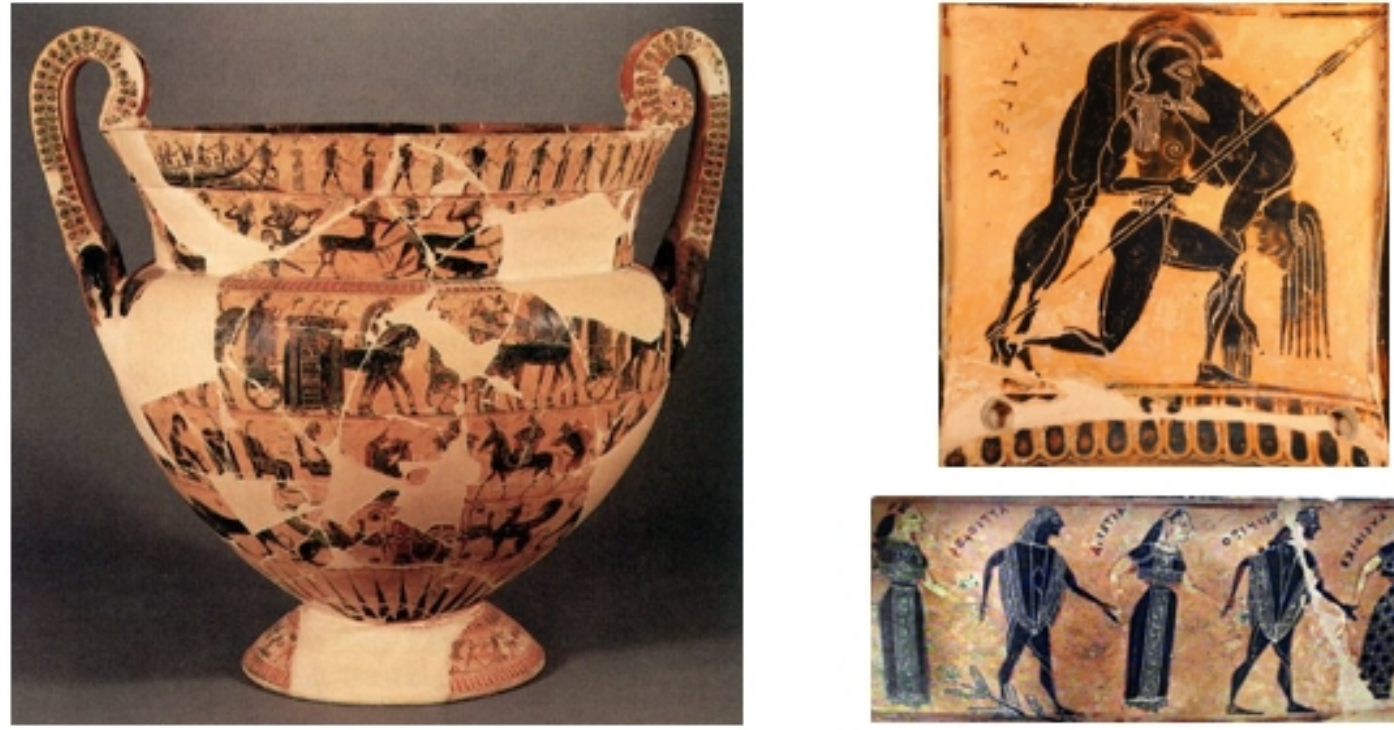

Görsel 2. Françoise vazosu, M.Ö. 570-560

MÖ 570-560 yıllarına tarihlenen Françoise vazosu, çömlekci Ergotimos ile ressam Kleitias'ın imzasını taşır (Kleiner, 2010, s. 101). Bu vazo üzerinde de Homeros'un İlyada'sının en önemli kahramanı Aşil, (Achilles) ile karşılaşırız. Aşil, ölümlü baba Thetis ile tanrıca Pelaus'un oğludur. Vazo üzerindeki betimlemelerde, Tetis ve Pelaus'un düğünü ile Troya savaşı işlenmiştir. Antik dünyanın en popular düğününe bütün tanrılar katılır. Altı adet friz içerisinde betimlenen tüm tanrılar ve nesneler yazıyla etiketlenmiştir. Bu yazılı etiketler bir durumu yada olayı aktarmaz ancak, mitolojik öykünün yorumlanmasına katkı sağlar (Strawczynski, 1998, s. 107) .

Yunan vazo resminde yaygın bir kullanıma sahip yazılı ifadelere Roma seramik kültüründe daha az rastlandığını söylemek yanlış olmayacaktır. Yazının seramik yüzeylerde kullanımı 9. Yüzyılda İslam coğrafyasında yeniden yaygınlaşır. İslam sanatına özgü kaligrafik uygulamalar, sadece kitap sanatında değil seramik form ve mimari yüzeylerde de önem kazanır.

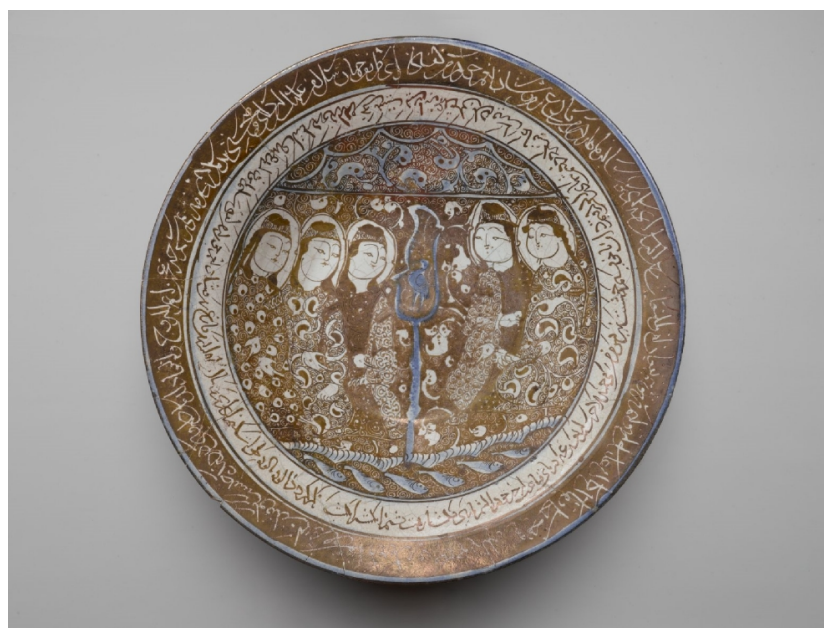

Görsel 3. Lüsterli Tabak, 8.6 x 33cm 13. yüzy1l, Tebriz, Brooklyn müzesi

Tabak, kase, küp gibi geleneksel seramik formlar üzerinde görülen kaligrafik uygulamalarda çoğunlukla dini inaçlara ilişkin sözler, sahibine bolluk ve bereket dilekleri yeralır (Watson, 2004, s. 206), (Charleston, 1977, s. 77). Bu tür uygulamalarda, metnin okunurluğunun gözardı edildiği, simetrik ve aynalanmış örneklerde yazı salt görsel bir eleman olarak kullanılmıştır.

İslam seramiğinde çok yaygın olmamakla birlikte, yazının figüratif unsurlarla beraber kullanıldığı örneklerde 
ünlü şairlerin, edebiyatçıların mısralarına rastlanır. 13. yüzyıla tarihlenen bir lüster tabakta, resimsel betimleme yazıyla birlikte düzenlenmiştir. Fars edebiyatına özgü mistik kuş ve 1şı temasına gönderme taşıyan bu tabağın iki bordürlerinde İranlı mutasavvıf Şems-i Tebrîzî'nin dizeleri yer almaktadır (Art, 2009). Mevlana Celâleddîn Rûmî'nin manevi ustası olarak kabul edilen Şems-i'nin tabağın yüzeyini dolanan dizelerinde sevgiliye duyulan özlem ve aşk teması işlenmiştir. Bu örnekte yazının resimsel betimlemeyi bütünleyen bir işlev yüklendiği söylenebilir.

Yukarıda sıralanan örneklerden de izlendiği üzere, yazı hem bir süsleme unsuru hemde dilsel bir ifade aracı olarak seramik yüzeylerde binlerce yıldır varlığını sürdürmektedir. Yazının seramik form ve yüzeylerle olan tarihsel birlikteliği bugün mimari ve işlevsel seramiklerden, sanatsal çalışmalara taşınmıştır. Şüphesiz bu durum 20. Yüzyılın ilk yarısında gelişen sanatsal hareketler ile yüzyılın ortalarındaki yeni sanatsal ve düşünsel eğilimlerden bağımsız düşünülemez.

\section{4. Çağdaş sanatta yazı}

20. yüzyıl yazının/metnin sanatsal temsilin yerini aldığı bir çağdır. Bir ifade aracı olarak yazı, edebiyatın alanıdan sızarak, plastik sanatlar alanına yerleşir. Yüzyılın başlarında Kübist ve Dadaist işlerde salt görsel bir unsur, plastik bir eleman olarak ortaya çıkar. Yüzyılın ikinci yarısında Kavramsal çalışmalarda görsel bir imgeye dönüşerek, sanatsal temsilin yerini alır. Günümüzde çağdaş sanatın faklı alanlarında her iki yaklaşımı içeren çok sayıda örnekle karşılaşmak mümkündür.

Araştırmanın odağını oluşturan seramik çalışmalarda yazı kullanımını incelemeye geçmeden önce, 20. Yüzyılda sanattaki dönüşümlerle birlikte, sanat kanonu içinde yer edinmiş yazı ve metin içeren eserler saptanmaya çalışılacaktır.

Sanatsal çalışmalarda yazı kullanımına ilişkin ilk örnekler, Pablo Picasso ve Georges Braque, John Heartfield gibi Kübist ve Dadaist sanatçıların kolajlarında karşımıza çıkar. Bu çalışmalarda, gazete ve mecmualardan koparılmış yazı ve metinler görsel bir eleman olarak resim yüzeyine dahil edilmiştir. Parçalanmış, okunabilirlikten uzak bu metinler salt plastik yapıyı güçlendirmeye hizmet eder.

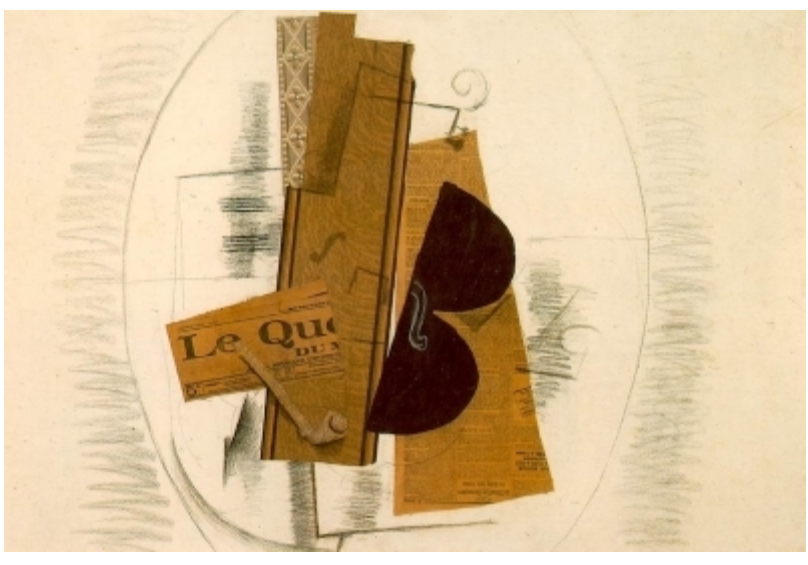

Görsel 4. Georges Braque, 1919

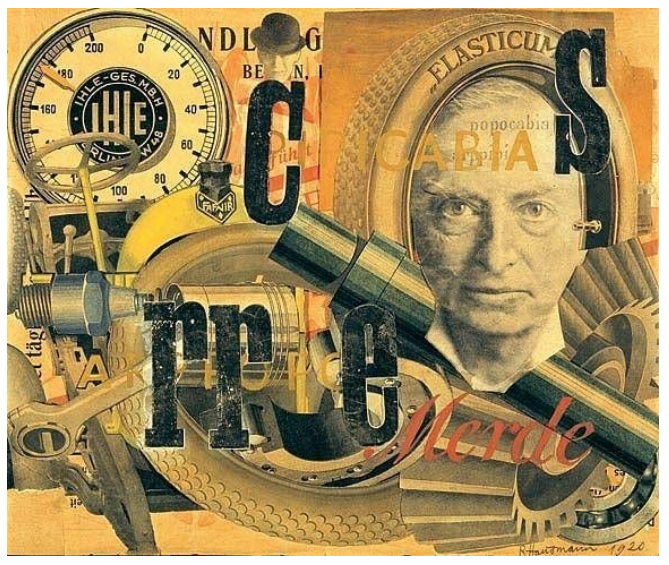

Görsel 5. Raoul Hausman, 1919

Kübist kolajlarla görsel benzerlikler taşıyan Dadaist Fotomontajlarda yazının ve fotografik imgelerin birlikte kullanıldığı görülür. Estetik kaygının öncelendiği apolitik Kübist kolajların aksine, politik içerikli Dadaist fotomontajlarda yazı ve fotografik imgeler bağlamından koparılarak yeniden düzenlenmişlerdir. Dadaist sanatçı Raoul Hausman, 1918 başlarında metne odaklanan fotomontajlarında “...sözel göstergeleri grafik ve fonetik fragmanlara bölerek yeniden biraraya getiriyordu. Dizgi karakterlerini rastgele art arda koyarak oluşturduğu anlamsız harf dizileriyle afişler üretti, onları çoğaltıp Berlin sokaklarına astı. İfade aracı olma işlevini ortadan kaldırarak dili özgürleştiriyordu" (Altınyıldız Artun ve Artun, 2018, s. 342). Bir başka Dadaist sanatçı, John Heartfield ise anti-faşist propaganda içeren fotomontajlarında, sözcükleri parçalamak yerine anlam bütünlüğünü koruyacak şekilde kullanmayı tercih ediyordu. Heartfield böylece fotografik imge ve yazının birlikte kullanıldığı fotomontajlarında bilgi aktarımını hedeflemişti (Altınyıldız Artun ve Artun, 2018, s. 347).

Dadaist sanatçıların çalışmalarında yazı bir ifade aracı olarak ortaya çıkarken, Sürrealist sanattçı Rene Magritte'in çalışmalarında ise dil ve imge arasındaki ilişkiyi yıkmaya yönelik bir eylem olarak karşımıza çıkar. Magritte, 'Rüyaların Dili' ve 'Bu Bir Pipo Değildir' adlı çalışmalarında algımızla oynayarak, gerçekliği sorgulamamiza neden olur.

20.Yüzyılın ortalarına gelindiğinde Andy Warhol, Campell ve Brillo kutularıdaki yazılarıyla gerçekliğin yıkılmasına neden olmuştur. 1960’’ı yıllarla birlikte, sanatsal çalışmalarda plastik deneyimin yadsındığı, 
düşünsel deneyimin önem kazandığı bir sürece girilmiştir. İzleyicinin estetik deneyimden ziyade, zihinsel bir sorgulama sürecine yönlendirildiği kavramsal çalışmalarda yazı/metin öne çıkar. Öyleki Joseph Kosuth, Lawrence Weiner ve Art and Language grubunun çalışmalarında, sanatsal temsil yerini ‘metne' bırakır.

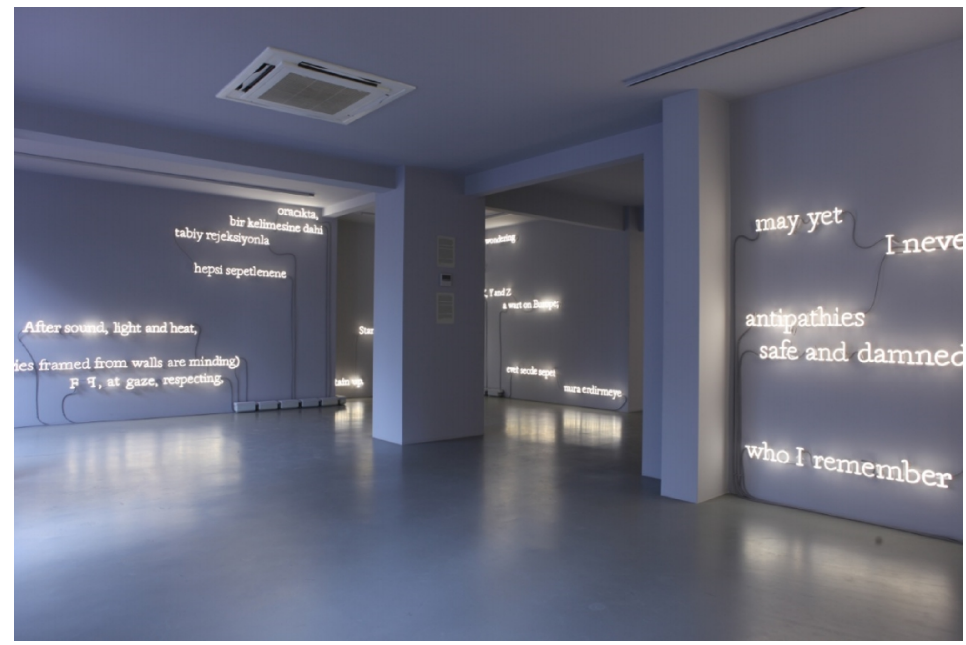

Görsel 6. Joseph Kosuth, Uyanma, 2012

Kavramsal sanatın kült çalışmaları arasında yer alan Joseph Kosuth'un 'Bir ve Üç Sandalye adlı düzenlemesi'nde olduğu gibi, metin düzenlemenin bir parçasıdır. Tıpkı sandalyenin fotografik imgesi gibi, anlam ve değer yitirmeden, çoğaltılabilir, tekrar edilebilir. Kosult'un 1985 tarihli 'sıfır ve değil' 2012 tarihli 'Uyanma' adlı çalışmaları, varolan metinlerin mekana yayılan tekrarıyla hem mekanın yeniden algılanmasını, hem de metne ilişkin yeni okumaların gerçekleştirilmesini olanaklı kılar. Sanatçı, Uyanma adlı çalışmasında, James Joyce'un Finnegans Wake kitabından alıntıladığı metinleri kullanır. Kosult, 'The Wake'in oluşturduğu paramparça düşün bütününün parçalarından ve parçasının bütününden ben de kendime bir yapı kuruyorum, farklı bir bütün, bu bütün bana ait, ama parçalar ondan'der (Madra, 2012). Galeri mekanının bir kitap gibi tasarlandığı düzenlemede, metinlerin yerleşiminde orjinal kitap sayfalarına sadık kalınırken, bazı satırlar dışarda bırakılarak metin eksik inşa edilmiştir. Bu eksiklik varolanın görünürlüğünü ve okunurluğunu arttırmaya yönelik bir hamle olarak değerlendirilebilir.

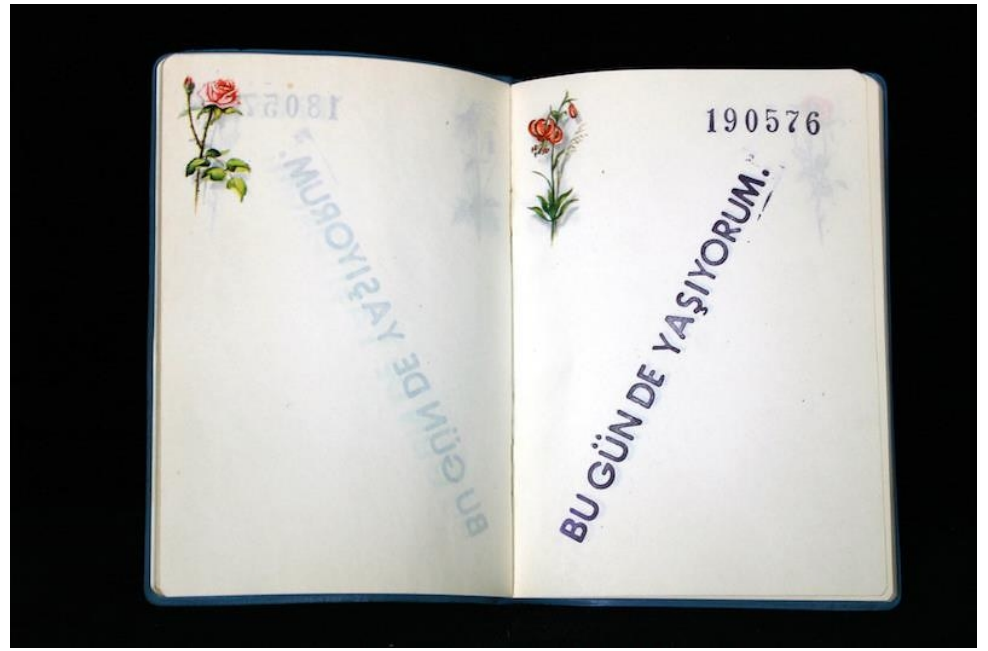

Görsel 7. Cengiz Çekil, Günce, 1976

Kavramsal sanatın Türkiye'deki temsilcilerinden Cengiz Çekil'in çalışmalarında yazı ve metin dilsel bir araç ve bellek yardımcısı olarak olarak karşımıza çıkar. Sanatçının 'Ele Geçirilmiş Mektuplar', 'Yaşanmış Bir Yılın Takvimi', 'Günce' adlı çalışmaları metin temelinde şekillenmiştir. 1976 tarihli 'Günce', Türkiye'nin oldukça sıcak politik ortamında; Çekil'in deyimiyle "hayatla ölümün sokakta birlikte dolaştı̆̆ o gergin atmosferde" (Altunok, 2015) gelişir. Çekil, her günün sonunda eve ulaştığında, gece günlüğüne not düşer: 'Bu Günde Yaşıyorum' (Altunok, 2015). Matbaa harflerinden yapılmış bir mühür ile tutulan bu not, adeta o günün Türkiye'sinin sessiz bir kaydıdır. Çekil bu çalışmaya ilişkin bir konuşmasında "[...] çok kasvetli, ölümün 
kutsandığı, korku ortamının olduğu bir dönemde tepki olarak 'Yaşamak en önemli şeydir'i vermek istedim”' der (Cengiz Çekil, 2011).

Aynı yıllarda, kavramsal çalışmaların aksine, metnin içeriğinin silikleştiği, yazının salt görsel bir eleman olarak kullanıldığı örneklerleden de söz edilebilir. Ergin İnan, gerek el yazısı mektupları, gerekse kitap sayfalarını kullandığı çalışmalarıyla Türkiye sanatında kendine ayrıcalıklı bir yer aralamıştır. İnan'ın çalışmalarında yazı salt görsel bir eleman olarak karşımıza çıkar. 1980'li yılların sonlarında ürettiği 'Mesnevi' serisinde farsça eski kitap sayfası kolajlarından yararlanmışıı. (Giray, 2001, s. 188-196) Sanatçının yaşadığı coğrafyaya yabancı bir dilin, arapçanın, göstergelerini kullandığı yapıtlarında yazılar yeni bir anlam kazanır. Kutsal kitabın alfabesi, çalışmanın içeriğine mistizim katarken, geçmişe, çok gerilerde kalmış zaman dilimlerine göndermeler içerir.

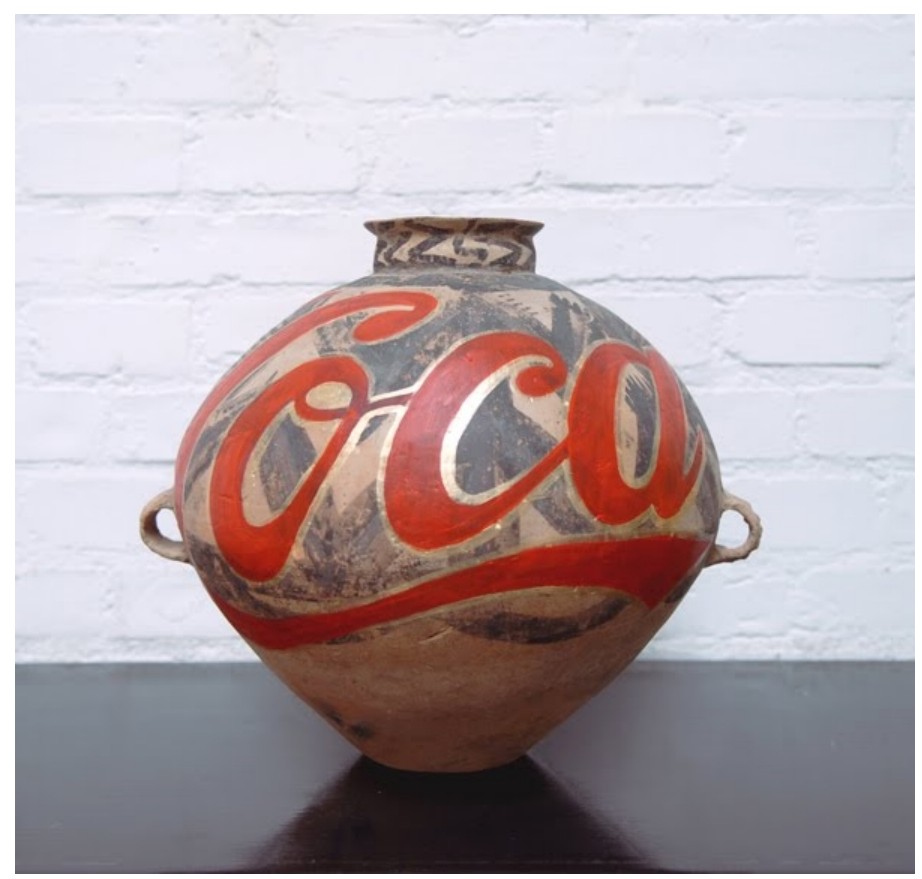

Görsel 8. Ai Weiwei, Coca Cola logolu kap, 1997, Neolitik dönem M.Ö 5000-3000

Yazının hem bir belge hemde görsel bir eleman olarak kullanıldığı en güçlü işlerden biri hiç şüphesiz, Çinli sanatçı Ai Weiwei'nin 1995 Tarihli 'Coca Cola logolu Çömlek' isimli çalışmasıdır. Bu çalışma seramiğin tarihsel ve kültürel bağlamı üzerinden bir siyasal sistem eleştirisi içermektedir.

Ai'in, Çin'in tarih ve kültürü üzerine odaklanan çalışmaları, eğitim için gittiği Amerika Birleşik Devletleri'nden ülkesine geri döndüğü 1990’lı yılların ortalarında başlar. Bu yıllar aynı zamanda Çin'de politik ve kültürel dönüşümün hız kazandığı yıllardır. Ai Weiwei'nin 'Coca Cola logolu Çömlek' isimli, müdahale edilmiş antik vazo çalışması, işte bu dönemde ortaya çıkmıştır (Kataoka, 2012).

Ai, bir antikacı dükkanından satın aldığı, Han Hanedanlık dönemine ait, yaklaşı 2000 yıllık antik form üzerine 'Coca Cola' logosunu boyar. O sadece bir içecek ismi değil, aynı zamanda geçtiğimiz yüzyılda tüketim kültürünün en güçlü sembollerindendir. 1990'larda kapalı ekonomiyle yönetilen Çin Halk Cumhuriyeti'nde ise kapitalizmin bir sembolü olarak karşımıza çıkar (Başar, 2018, s. 159).

Ai'nin, özel korumalı müze vitrinlerinin içinde izlemeyi beklediğimiz, Çin hanedanlık dönemine ait, yaklaşık ikibin yıllık bir seramik kabın kültürel ve tarihsel değerini yok sayarak, boyadığı logo şüphesiz vandalist bir girişimdir. Ancak çalışma gücünü ve etkisini bu vandalist yaklaşımdan almaktadır. Çin'in antik dönem seramik süslemelerini çağrıştıran Ai’nin çalışmasında, 'Coca Cola' yazısı görsel bir imge olarak değerlendirilebilir. 


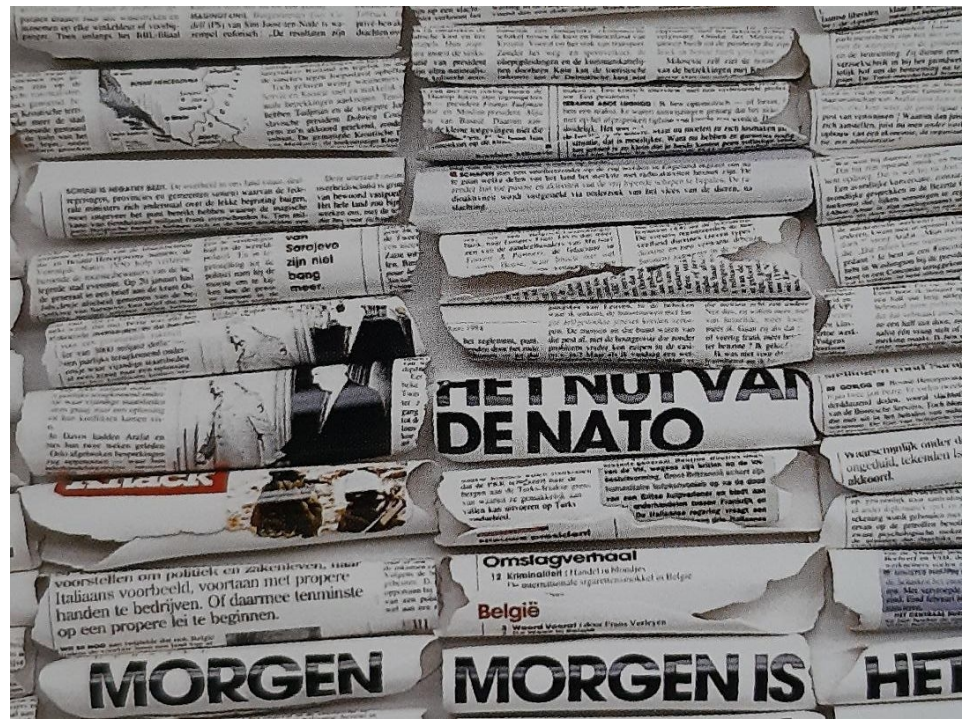

Görsel 9. Jeanne Opgenhaffen, Kayıp Cennet, Seramik,1995

Yazıyı çalışmalarında bir dilsel araç olarak kullanan bir başka sanatçıı Jeanne Opgenhaffen'dır. Belçikalı sanatçı Opgenhaffen toplumsal sorunlara işaret eden erken dönem işlerinde yazı ve metinlerden yararlanmıştır. 1995 tarihli 'Kayıp Cennet' adlı çalışması savaş, göç, uyuşturucu, çevre kirliliği, işsizlik, ırkçılık, yozlaşma gibi yaşamımızı tehtit altına alan ve giderek büyüyen sorunlara odaklanır (Scott, 2001, s. 159). Gazetelerin iç sayfalarına gizlenen, giderek kanıksanan sorunları görünür kılar.

Sanatçı günlük gazetelerde yer alan haberlerin bir bölümünü olduğu gibi, bir bölümünü ise anlamı bozacak şekilde yeni söz dizilimleriyle seramik yüzeye aktarır. Gazete manşetlerini andıran iri puntolu metinlerde 'beklemek' ve 'yarın' kelimeleri ard arda tekrar edilmiş; 'kraliyet taçı', 'yarın iyidir', 'temiz bir kelimedir' ifadeleri öne çıkarılmıştır. Okunurluğu artırılan tüm bu günlük yaşama ait kelime ve ifadeler herhangi bir olumsuzluk içermez. Aksine, çalışmanın tam merkezinde yer alan Nato kelimesiyle aralarda yazılı olan Saraybosna kelimelerinin algılanmasını zorlaştırırlar.

Saraybosna sadece coğrafi bir bölgenin adı değil bir trajedinin adıdır. Yugoslavya'nın dağılmasının ardından yaşanan iç savaşta binlerce Boşnağın öldürüldüğü Saraybosna'daki katliama bütün dünya sessiz kalmıştır. Uluslararası askeri bir ittifak olan NATO ne yazıkki olayların başlamasından üç yıl sonra Srebrenitsa katliamının ardından, 1995'te müdahale kararı alır. 'Kayıp Cennet', yüzyılın en büyük trajedilerinden biri yaşanırken insanlı̆̆ın kısılan sesini, daha iyi bir yarın sloganları arkasına gizlenen sansürü; bir başka ifadeyle çağımız insanının giderek yitirdiği insani değerlerini işaret eder.

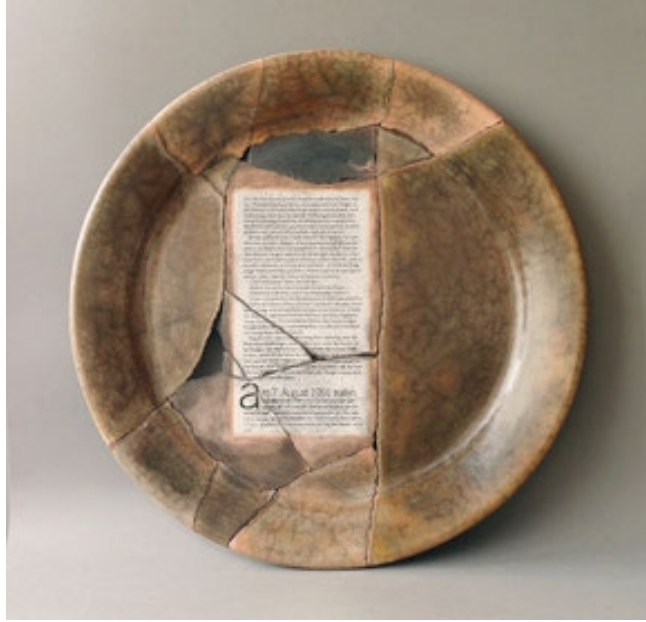

Görsel 10. Patrick King, Saraybosna,1993-95

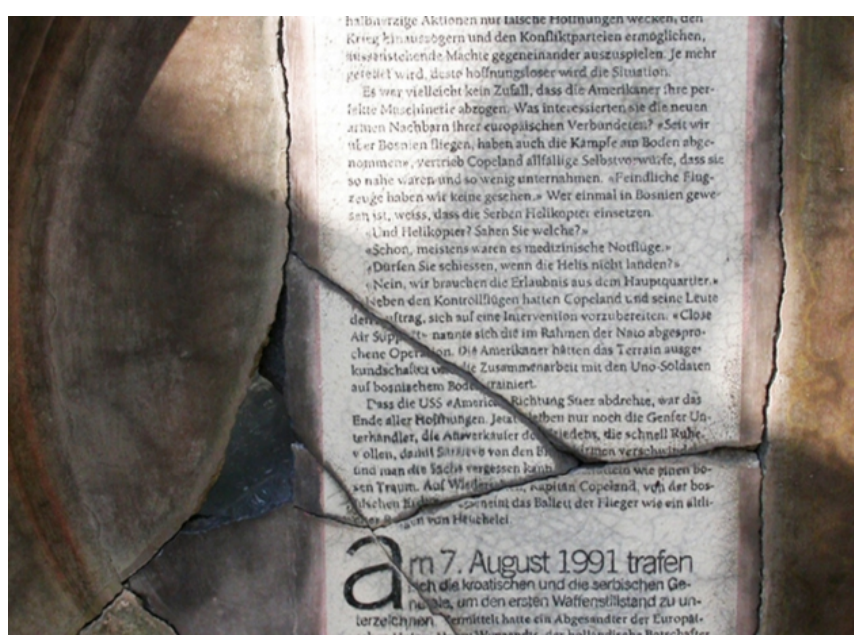

Görsel 11. Patrick King, Saraybosna detay

Jeanne Opgenhaffen'ın 'Kayıp Cennet' adlı çalışmasında dolaylı olarak değindiği Yugoslavya iç savaşı, Patrick King'in 1990'lı yıllardaki bir dizi çalışmasının ana konusunu oluşturur. Bir sanatçı olarak toplumsal sorunlara odaklanan King, bireysel ve toplumsal şiddet karşıtı işler üretir (Scott, 2001, s. 160). Patrick King seramik çalışmalarında yazılı metni hem görsel bir unsur hemde belgesel bir araç olarak kullanmıştır. King'in 
'Saraybosna' adlı çalışma serisi, seramik geleneğinin en bilindik formları tabak ve kaselerden oluşmaktadır. 1990'lı yılların ortalarına denk düşen bu çalışmalar, Yugoslavya'nın parçalanmasını takiben yaşanan iç şavaşı, Bosna'daki şiddeti konu alır. Sanatçı günlük gazetelere yansıyan haberleri adeta hafızalarımızdan kazınmasını engellemek istercesine seramik yüzeylere kazır. Seramik üretim geleneğinin en temel formu tabak ve kaseler üzerinde yerleştirilen haber metinleri ilk anda, erken dönem İslam seramiklerinde kullanılan yazılı dekorasyonu anımsatsa da bu sadece bir anlık yanılsama oluşturur. Patrick King'in parçalanmış ve büyük bir titizlikle yeniden birleştirilmiş formları savaşa rağmen umudun hala var olabileceğinin altını çizer. Trajedinin en önemli delili olarak tabağa aktarılan gazete küpürleri, yazılı metinler adeta hafizalarımıza atılan bir çapa işlevi görür. Kırılıp parçalanmış ve sonrasında özenle yapıştırılmış tabak formlarını bir umut sembolü olarak görmek yanlış olmayacaktır.

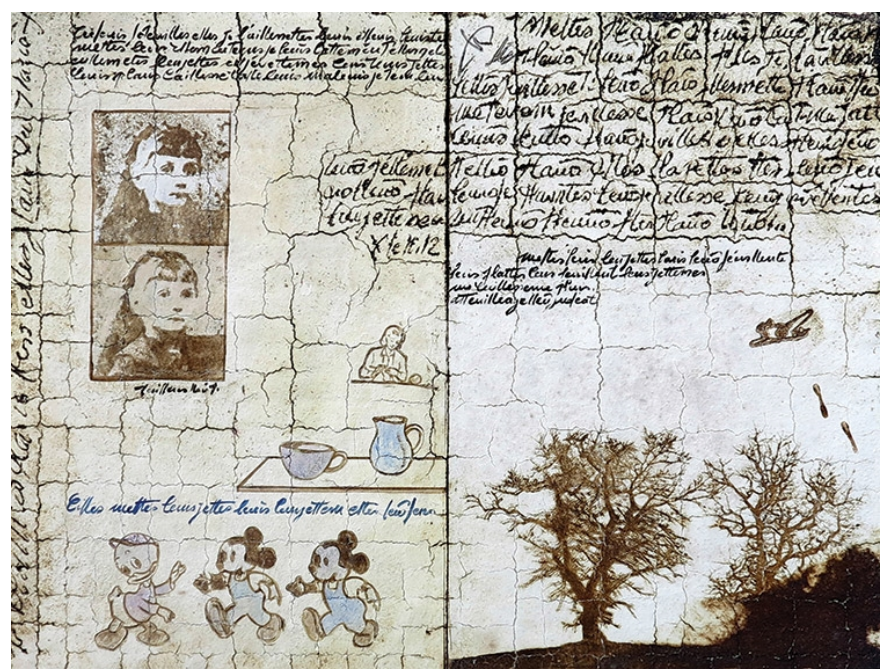

Görsel 12. Marianne Requena, Seramik, 1990

Fransız sanatçı Marianne Requena erken dönem işlerinde kendi kişisel tarihinden beslenirken son dönem çalışmalarında yaşadığı zamanın toplumsal sorunlarına eğilmektedir. Çağımızın en önemli sorunlarından biri, 'şiddet', 'savaş' ve 'açlık' son dönem çalışmalarının ana konusunu oluşturmaktadır (M. Requena, Kişisel İletişim, 15.04.2019). Requena, çalışmalarında gazete ve mecmualardan alınmış fotografik imgelerle yazılı metinleri yan yana, iç içe kullanır. Yazının plastik bir unsur olarak kullanıldığı büyük boyutlu seramik yüzeyler, adeta bir gazate mizanpajı gibi düzenlenmiştir. Sanatçı metinleri kendi elyazısı ile yüzeye aktarır. Bu, sanatçının varoluşuna dair önemli bir belgedir. Marianne Requena'nun metinleri tam olarak çözümlenemez. Yaşanılan, söylenilen ve hissedilen duygulara dairdir. Bir başka ifadeyle bu metinler onun ve bizim varlığımızın kanıtıdır (Biennale, t.y.).

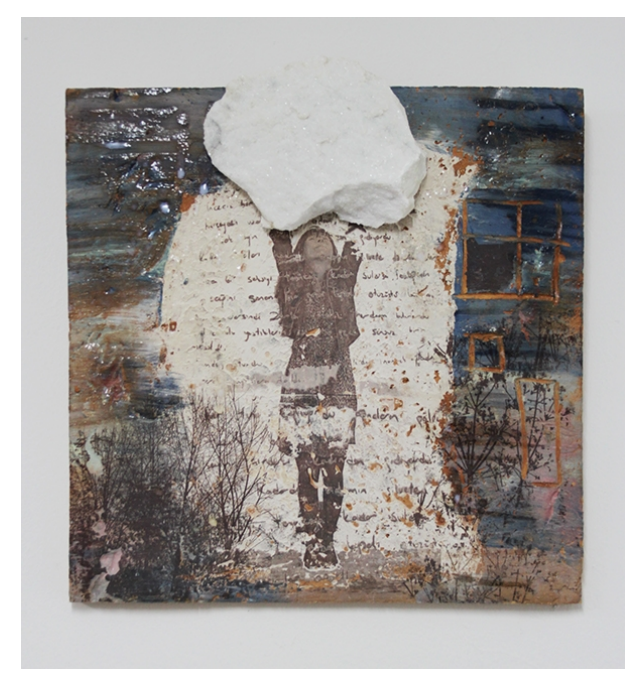

Görsel 13. Duygu Kahraman, Bulut Geçti I

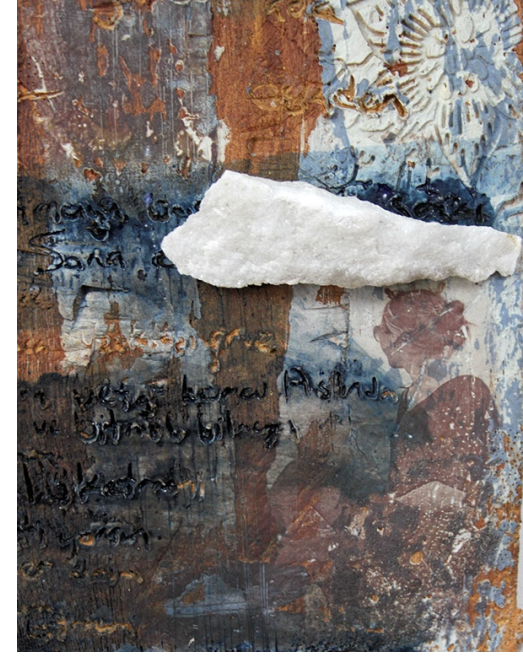

Görsel 14. Duygu Kahraman, Bulut Geçti II

Yazının plastik bir unsur olarak kullanımında Marianne Requena ile benzer bir yaklaşım Duygu Kahraman'nın çalışmalarında karşımıza çıkar. Kahraman, kendisinin kaleme aldığı aşk, sevgi ve ayrılık temalarını işlediği lirik dizeleri figüratif imgelerle birlikte kullanır (D. Kahraman, Kişisel İletişim, 05.05.2019). Dikkatle bakıldığgnda 
bu fotografik imgelerin sanatçının kendisine ait portre ve günlük yaşamdan enstantenelerden oluştuğu görülmektedir. 'Taşı Seversen Altında Ezilirsin', 'Bulutların altında' isimli çalışma dizisinde sanatçı metinlerini kil tabletler üzerine kazıyarak yada boya ile aktarmıştır. Yüzeyde fotografik imgenin içinde eriyen yazı, yer yer silikleşirken bazı bölgelerde daha okunaklı hal almaktadır. Metnin okunmasını zorlaştıran bu oyunsu kurgu, feminist eleştiri üzerine çalışan Elaine Showalter'ın kadınların farklı iki dil kullanarak konuştukları görüşünü anımsatır. Showater kadınların yazdıkları metinlerin 'çift sesli söylemler' olduğunu, hem susturulmuş, hem de toplumdaki hakim grubun kültürel ve sanatsal mirasını yansıttığını ileri sürer (Peterson \& Mathews, 2008, s. 39). Showater'ın metin üzerine ileri sürdüğü bu görüşlerin izlerini Duygu Kahraman'ın yazılı ve plastik dili üzerinde aramak yanlış olmayacaktır. Kahraman’ın çalışmaları her ne kadar kendi kişisel tarihiyle ilişskili olsada, susturulmuş bir grubun sesi olarak da okunabilir.

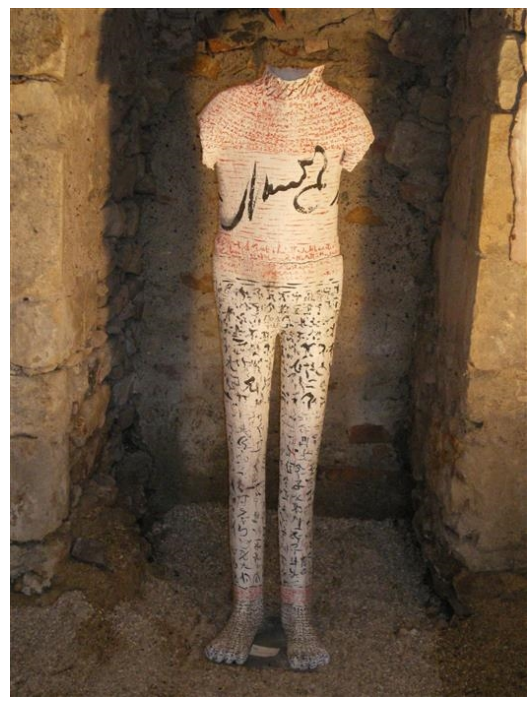

Görsel 15. Colette Biquand, seramik

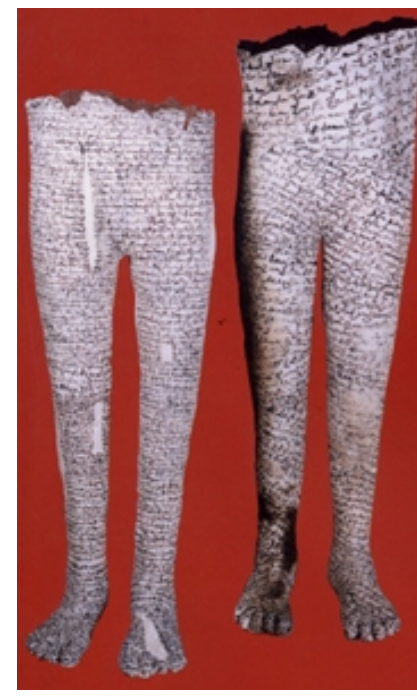

Görsel 16. Colette Biquand, seramik

Çalışmalarında yazıyı plastik bir unsur olarak kullanan Colette Biquand'ın parçalanmış terracotta bedenleri, kadın yada erkek gibi herhangi bir cinsiyeti işaret etmeksizin doğrudan insanoğluna odaklanır. Anatomik özenden uzak pirimitif dönem heykellerini andıran çalışmalar adeta bir kabuk gibidir. Can ile tenin ayrıştığı mistik bir ana tanıklık hissi uyandırırlar. Bedenin yüzeyini kaplayan farklı kültürlere ait yazı karalamaları bu mistik, uhrevi atmosferi güçlendirmektedir. Latin alfabesi ile üstüste bindirilmiş Arap, Japon ve Çin alfabesine gönderme yapan karalamalara sadece dekoratif bir eleman olarak yaklaşmak doğru olmayacaktır. Sanatçı, onları başka bir evrenin, başka bir zamanın kayıp dili olarak algılamak gerektiğini ifade eder (Schvalberg, 2019, Pr.18). Colette Biquand'un çalışmaları insanlık tarihini, bir anlamda bizim kayıp tarihimizi işaret eder.
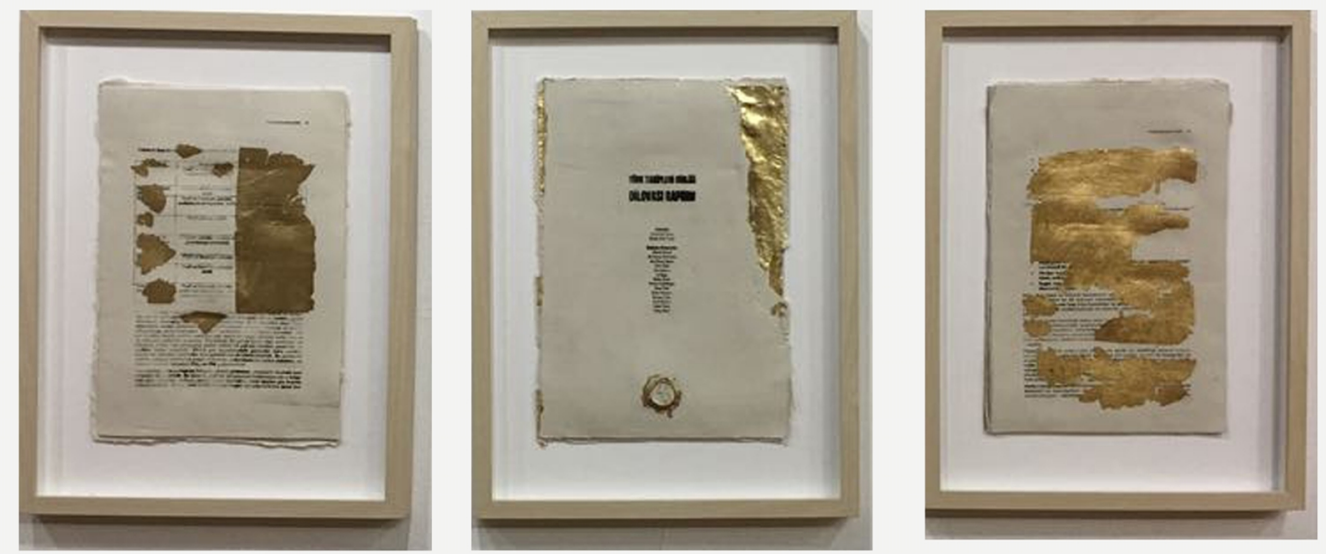

Görsel 17. Safiye Başar, 'Dilovası Üzerine Yeni Bir Okuma Önerisi II’, kağıt katkılı porselen, 2014

Toplumsal cinsiyet, emek ve çevre konuları üzerinden çalışmalarını sürdüren Safiye Başar 'Dilovası Üzerine Yeni Bir Okuma Önerisi II' adlı çalışmasında yazıyı hem plastik bir unsur hem de bir belge olarak kullanmıştır. Çalışma, Türkiye sanayi’nin kalbi olarak tanımlanabilecek Dilovası bölgesinde yaşanan çevre kirliliği ve sağlık problemlerine odaklanır. TTB'in Dilovası üzerine hazırladığı bir rapordan bazı sayfaları seramik yüzeye aktaran Başar, bölgenin toprağında, havasında insan sağlığını tehtit edecek boyutlara ulaşan ağır metallerin varlığına 
ilişskin bilgileri altın varaklarla kapatarak metnin anlam bütünlüğünü ortadan kaldırmıştır. Böylece bilimsel verilere dayalı olumsuzluk içeren bilgi altın varakların altında gizlenerek yeni bir okuma önerisi olarak sunulmuştur. Başar'ın bu yaklaşımı bugün ekonomik ve politik kaygılarla manüple edilmeye çalışan bilimsel bilgiye işaret eder. Antik dönem kil tabletlerle binlerce yıl öncesinden bu güne aktarılan veriler gibi Başar'ın porselen sayfalarının, zamanın aşındırıcı gücüne karşın, gerçek bilgiyi geleceğe taşımayı amaçladığı söylenebilir.

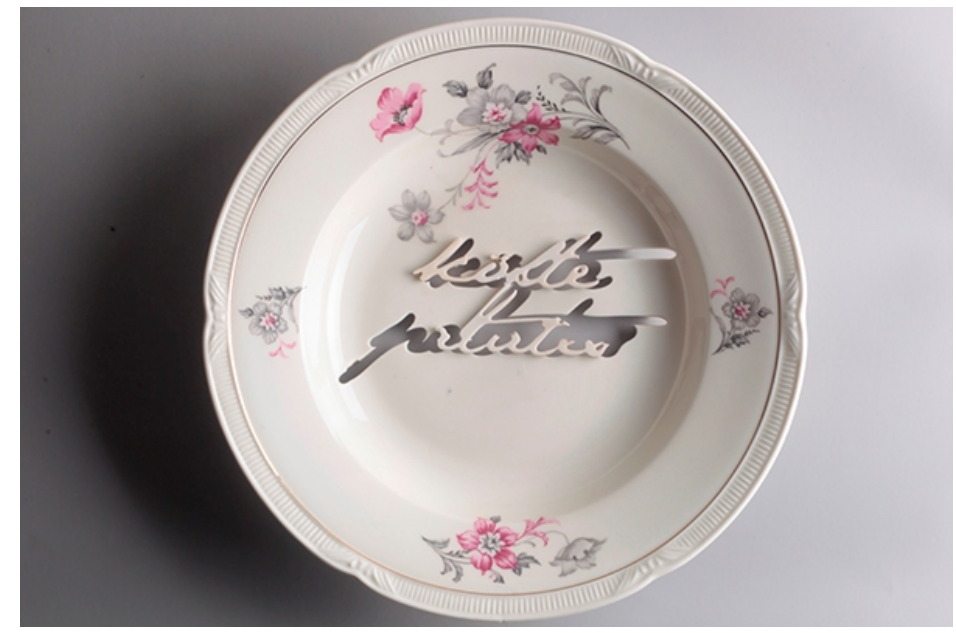

Görsel 18. Elif Ağatekin, Aşkın Damakta Kalan Tadı, kullanılmış porselen nesne, 2013

Yaşadığı döneme tanıklık eden ve bu tanıklıklarını seramik yapıtları aracılığıyla geleceğe taşıyan Elif Ağatekin, 'Aşkın Damakta Kalan Tadı' adlı çalışma serisinde kendi kişisel aile tarihine odaklanmıştır. Çalışmalarında çoğunlukla geri dönüşüm seramikleri kullanan Ağatekin, anneannesinin ölümünün ardından ona/ailesine kalan mirası hem çalışmasının konusu hemde malzemesine dönüştürmüştür. Sanatçı bir miras olarak kalan porselen tabaklar üzerine Anadolu yemek kültürüne özgü yemeklerin, anneannesinin yemeklerininin isimlerini yazarak, adeta büyük aile sofralarının birleştirici ruhunu ölümsüz kılmak ister. Ağatekin, bu seriye ilişkin görüşlerini açıklarken "Tüm ömrünü büyük bir aşkla bize muhteşem yemekler yaparak geçiren anneannem, eksiksiz sofrasında biz yerken gözlerimizin içine bakar, biz yedikçe o doyardı sanki. (...) Tek bir kez daha onun sofrasında o müthiş tatlarla dolabileceğini bilsem; ne toplardım, ne de yazardım tadı damağımızda kalan o yemeklerinin adlarını o eski tabakların üzerine” der (Ağatekin, 2013).

Ağatekin'in bu çalışması her ne kadar sanatçının kendi kişisel tarihiyle ilişki görünsede, onu Anadolu coğrafyasında toplumsal rollerin dağılımını üstü örtük biçimde gösteren bir çalışma olarak okumak hiçte yanlış olmayacaktır. Yakın bir zamana kadar içinden yemek yenilen bu porselen tabakların yüzeyi kesilip boşaltılarak oluşturulan yazılar artık sadece yemeğin ismi değildir. Onlar eş ve çocukları, torunlarıda içine alan bir büyük ailede kadının görev alanına işaret eder. Bir başka ifadeyle, kadının bir ömür adadığı ev içindeki sorumluluk alanının sınırlarını görünür kılar.

\section{Sonuç}

Binlerce yıldır bir iletişim biçimi ve bellek kaydedici araç olarak yazı, tipografik ve kaligrafik özellikleriyle 20 . Yüzyılın başlarında edebiyat ve yazın dünyasından sanat alanına geçiş yapmıştır. Önceleri kübist ve sürrealit çalışmalarda görsel bir imge olarak karşımıza çıkarken yüzyılın ikinci yarısında, kavramsal sanatla birlikte yüzlerce yıllık geleneği yıkarak sanatsal temsilin yerini alır.

Seramik malzemenin çağdaş sanata eklemlendiği geçtiğimiz yüzyılın ikinci yarısında formalist eğilimlerin hakim olduğu, yüzyılın sonlarına doğru ve günümüzde kavramsal yönelimlerin arttığı söylenebilir. Seramik malzemenin plastik dilinden ve tarihsel bağlamından yararlanılan pek çok çalışmada yazının görsel bir eleman olarak kullanıldığı gözlenmektedir. Ai Weiwei, Jeanne Opgenhaffen, Elif Ağatekin, Safiye Başar'ın çalışmalarında da izlendiği gibi, kavramsal temelli işlerde yazı bir göstergeler bütünü, bellek kaydedici dilsel bir araç olarak işlev görmektedir. Estetik kaygıların merkeze alındığı Marianne Requena, Colette Biquand ve Duygu Kahraman'nın çalışmalarında ise metin içerikten bağımsız, bir 'yazı imgesi' olarak plastik yapıyı güçlendirmeye hizmet etmektedir. Her iki yaklaşımla ortaya konan çalışmalarda ağırlıklı olarak toplumsal sorunların işlendiği gözlenir. Bunun yanında sanatçıların kişisel tarihlerine göndermeler içeren örneklerle de karşılaşılmaktadır. Araştırmada seramik malzemenin dili üzerinden çağdaş sanatta yazının görsel bir eleman ve dilsel bir araç olarak kullanımına ilişkin saptamalar yapılmaya çalışılmış bu konuda sınırlı sayıda sanatçı ve işine yer verilebilmiştir. Hiç kuşkususz bu liste, Ole Lislerud, Stephanie De Armond, Richard Milette, Beril Anılanmert, Candan Terwiel, gibi sanatçılarla genişletilebilir. 


\section{Kaynakça}

Ağatekin, E. (2013). Aşkın damakta kalan tadı. [Blog yazısı]. Erişim adresi: https://www.behance.net/gallery/ 12103437/The-Flavor-of-Love-Remaining-on-the-Palate

Altınyıldız Artun, N., \& Artun, A. (2018). Dada klavuz 1913-1923 Münih, Zürih, Berlin, Paris. İstanbul: İletişim Yayınları.

Altunok, Ö. (2015, $10 \mathrm{Kasım).} \mathrm{Cengiz} \mathrm{Çekil:} \mathrm{Sanat} \mathrm{yazanların} \mathrm{ilgilendiği} \mathrm{sanatçılardan} \mathrm{değilim} \mathrm{galiba...}$ Radikal. Erişim adresi: http://www.radikal.com.tr/kultur/cengiz-cekil-sanat-yazanlarin-ilgilendigisanatcilardan-degilim-galiba-1469813/

Art. (2009). Art of the Islamic world Erişim adresi: https://www.brooklynmuseum.org/opencollection/objects/ 125958

Başar, S. (2018). Çağdaş sanatta eleştirel bir dil olarak ironi ve seramik sanatındaki yansımaları. Atatürk Üniversitesi Güzel Sanatlar Enstitüsü Dergisi, 41, 154-165. doi: https://doi.org/10.32547/ataunigsed. 454525

Biennale Internationale De La Ceramique. (t.y.). Marianne Requena. Erişim adresi: http://www.biennaleceramique.com/2016/ceramistes/requena_marianne.html

Bulut, L. (1994). Kabartma Desenli Samsat Ortaçağ Seramikleri. Ege Üniversitesi Sanat Tarihi Dergisi, Say1: VII, s.1-18.

Cengiz Çekil MOMA'da. (2011, 5 Nisan). NTV Haber Bülteni. Erişim adresi: https://www.ntv.com.tr/turkiye/ cengiz-cekil-momada,yKEba53MmU-y64bSnuZPDQ

Charleston, R. (1977). World ceramics: an illustrated history. New York: Hamilyn Publishing.

Chiarini, S. (2018). The so-called nonsense inscriptions on ancient greek vases between paideia and paidia. Boston: Leiden Brill.

Clare, L. (2019). Göbekli Tepe. [Blog yazıs1]. Erişim adresi: http://webcache.googleusercontent.com/search?q= cache:XJHCRC8W5EcJ:http://sanliurfamuzesi.gov.tr/TR-178663/gobeklitepe.html\%2Bgöbekli+tepe+ tarihi\&safe $=$ active $\&$ hl $=\operatorname{tr} \& g b v=2 \& c t=c l n k$

Georges, J. (2010). Yazı insanlı̆̆ın belleği İstanbul: Yapı Kredi Yayınları.

Giray, K. (2001). Ergin İnan. İstanbul: İş Bankası Yayınları.

Graber, O. (1988). İslam sanatının oluşumu. İstanbul: Hürriyet Vakfı Yayınları.

Kataoka, M. (2012). Acording what?. D. Horowithz (Ed.), Ai Weiwei (s.8-22) içinde. Hong Kong: Prestel Publishing.

Kleiner, F. S. (2010). Gardner's art through the ages: the western perspective (Wadswarth cengage learning). Boston: Clark Baxter.

Madra, B. (2012). Joseph Kosuth. [Blog yazıs1]. Erişim adresi: http://www.beralmadra.net/exhibitions/josephkosuth/

Okur, E. (2007). Seramik sanatında bir tasarım ögesi olarak yazının kullanımı (Sanatta Yeterlik Tezi). Anadolu Üniversitesi Sosyal Bilimler Enstitüsü, Eskişehir. YÖK tez veri tabanından erişildi (Tez No. 211492).

Peterson, T. G., \& Mathews, P. (2008). Sanat tarihinin feminist eleştirisi. A. Antmen (Ed.), Sanat cinsiyet: sanat tarihi ve feminist eleştiri (s. 13-75) içinde. İstanbul: İletişim Yayınları.

Schvalberg, S. (2019). Les Corps De Colette Biquand. Erişim adresi: https://paragone.hypotheses.org/4631

Scott, P. (2001). Painted clay. London: A \& C Black Publishers.

Stokstad, M. (1995). Art history. New York: Harry N. Abrahams Publishing.

Strawczynski, N. (1998). L'inscription comme élément décomposition. Mètis. Anthropologie des mondes grecs anciens, 13, 107-121.

Voutiras, E. (2007). The Introduction of The Alphabet. A.-F. C. A.-Ph Christidēs (Ed.), in A history of ancient Greek: from the beginnings to late antiquity (p. 266-277). New York: Cambrigh University Press.

Watson, O. (2004). Ceramics from islamic lands. London: A\&Black Publishes. 


\section{Görsel Kaynakçası}

Görsel 1. Eyck, J.V (Sanatçı). (1434), Arnolfini’nin evlenmesi, [Yağlı boya]. Erişim adresi: https://www. tarihlisanat.com/ jan-van-eyck-arnolfini-nin-evlenmesi/

Görsel 2. Françoise vazosu. (İş). (MÖ 570-560), [Seramik]. Erişim adresi: https://www.florenceinferno. com/wp-content/uploads/2014/04/aiace_carrying_the-body_of_achille.jpg, https://www.ascsa.edu.gr/ uploads/media/hesperia/hesperia.80.3.0491.pdf

Görsel 3. Lüsterli tabak. (İş). (13. Yüzyıl) Tebriz, 8.6 x 33cm, [Seramik]. Brooklyn Müzesi. Erişim adresi: https://www.brooklynmuseum.org/opencollection/objects/125958

Görsel 4. Braque, G. (Sanatçı). Violin and pipe (1913), [Yağlı boya]. Erişim adresi: https://mymodernmet.com/ collage-art-collage/

Görsel 5. Hausman, R., (Sanatç1). (1919), [Kolaj]. Erişim adresi: https://www.google.com/search?q=Raoul+ hausman+art\&safe $=$ active \&source $=$ lnms\&tbm $=$ isch\&sa $=$ X\&ved=0ahUKEwiX16nqsTjAhWMp4sKHW duCeUQ_AUIESgB\&biw=1062\&bih=519\#imgdii=9hVJ112jNf3W3M:\&imgrc=v-drI6586KiTEM:

Görsel 6. Kosuth, J., (Sanatç1). (2012), Uyanma. Erişim adresi: http://www.beralmadra.net/exhibitions/josephkosuth/

Görsel 7. Çekil, C., (Sanatç1). (1976), Günce. Erişim adresi: https://www.flickr.com/photos/saltonline/ 37353815394/in/photolist

Görsel 8. Weiwei, A., (Sanatç1). (1997), Coca Cola logolu kap, [Seramik]. Erişim adresi: http://www. chipstone.org/article.php/479/Ceramics-in-America-2011/Mind-Mud:-Ai-Weiwei\%27s-ConceptualCeramics

Görsel 9. Opgenhaffen, J. (Sanatç1). (1995), Kayıp cennet, [Seramik]. Kaynak: Schot, P. Painted Clay, A \& C Black Publishers, s.160

Görsel 10. King, P., (Sanatç1). (1993-95), Saraybosna, [Seramik]. Erişim adresi: https://www.ceramicsonline. ch/patrick-king/gallery/

Görsel 11. King, P., (Sanatçı). (1993-95), Saraybosna, detay, [Seramik]. Erişim adresi: https://www.ceramicsonline.ch/patrick-king/gallery/

Görsel 12. Requena, M., (Sanatçı). (1990), [Seramik]. Erişim: http://biennale-ceramique.com/2016/ceramistes/ requena_marianne.html

Görsel 13. Kahraman, D., (Sanatçı). Bulut geçti I, [Seramik]. Erişim adresi: https://www.behance.net/ duygukahraman

Görsel 14. Kahraman, D., (Sanatç1). Bulut geçti II, [Seramik]. Erişim adresi: https://www.behance.net/ duygukahraman

Görsel 15. Biquand, C. (Sanatçı). [Seramik]. Erişim adresi: https://www.google.com/search?safe=active\&tbm= isch\&sa $=1 \&$ ei $=$ gmBEXcGLMMqYacTzqNAJ\&q $=$ colette + biquand + ceramic \&oq $=+$ Colette + Biquand\&gs _l=img.1.1.35i3912.48688.48688..50823...0.0..0.139.139.0j1.....0...1..gws-wiz

Görsel 16. Biquand, C. (Sanatçı). [Seramik]. Erişim adresi: https://www.google.com/search?safe=active\&tbm= isch\&sa $=1 \&$ ei $=$ gmBEXcGLMMqYacTzqNAJ\&q $=$ colette+biquand+ceramic \&oq $=+$ Colette + Biquand \&gs _l=img.1.1.35i3912.48688.48688..50823...0.0..0.139.139.0j1.....0....1..gws-wiz

Görsel 17. Başar, S. (Sanatçı). Dilovası üzerine yeni bir okuma önerisi II), [Kağıt katkılı porselen]. Safiye Başar koleksiyonu.

Görsel 18. Ağatekin, E. (Sanatç1). [Porselen]. Erişim adresi: https://www.behance.net/gallery/12103437/TheFlavr-of-Love-Remaining-on-the-Palate 